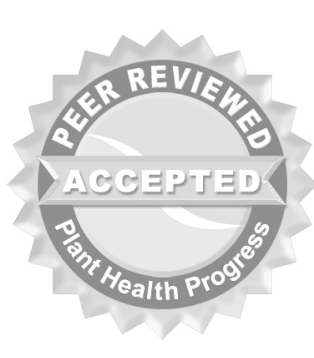

(c) 2006 Plant Management Network.

Accepted for publication 12 September 2006. Published 27 November 2006.

\title{
Biology and Distribution of Pryeria sinica, a New Pest of Euonymus Found in Virginia and Maryland
}

Peter B. Schultz, Hampton Roads AREC, Department of Entomology, Virginia Tech, Virginia Beach 23455; Eric R. Day, Insect I dentification Lab., Department of Entomology, Virginia Tech, Blacksburg 24061;

Adria Bordas, Virginia Cooperative Extension, Virginia Tech, Fairfax County, Fairfax 22035; and Richard Bean, Maryland Department of Agriculture, Annapolis 21401

Corresponding author: Peter B. Schultz. schultzp@vt.edu

Schultz, P. B., Day, E. R., Bordas, A., and Bean, R. 2006. Biology and distribution of Pryeria sinica, a new pest of Euonymus found in Virginia and Maryland. Online. Plant Health Progress doi: 10.1094/PHP-2006-1127-01-BR.

Unknown larvae feeding on Euonymus japonicus Bekomasaki at a private residence in 2001 and 2002 in Fairfax County, VA were subsequently identified by J ohn W. Brown, Systematic Entomology Laboratory, USDA in 2003 as Pryeria sinica Moore (Lepidoptera: Zygaenidae), a new North American record (1). Larvae were subsequently found in Maryland on 28 May 2003. The insect is found in two areas of Maryland and Virginia. In Virginia, P. sinica populations are located in the county and city of Fairfax approximately 21 miles west from the center of Washington, DC. The Maryland collection sites are from the county of Anne Arundel near the town of Glen Burnie, approximately 52 miles northeast of the center of Washington, DC.

Pryeria sinica is a Palaearctic species that occurs from Russia (Far East) and China through Korea, J apan, and Taiwan (2). Two genera, Celastrus and Euonymus, have been reported as host plants throughout the geographic range of $\mathrm{P}$. sinica. Yen and Horie (2) reared P. sinica from Celastrus punctatus Thunb, Euonymus sieboldianus Blume., and E. japonicus. They indicate that the geographical range of C. punctatus, the documented host plant in Taiwan, extends to South China and J apan, which coincides with the distribution of P. sinica. In Virginia and Maryland, P. sinica has been observed feeding on E. japonicus and Euonymus kiautschovicus Loes. 'Manhattan'. The origin of the Maryland and Virginia populations of P. sinica is unknown but introduction via nursery stock is suspected.

Pryeria sinica is univoltine in Virginia and Maryland. Egg hatch was observed on 17 March 2004, 18 March 2005, and 13 March 2006 at a range of 26 to 66 degree days $\left(50^{\circ} \mathrm{F}\right.$ base). Larvae are gregarious in late March and early April, initially feeding as leaf skeletonizers then later as leaf notchers on new foliage (Fig. 1). When disturbed the larvae drop by means of silk threads and if handled exude a sticky material. The larvae begin to disperse on the host plants in late April and early May, and most leave the host in mid-May prior to pupation. Pupation occurs at 430 to 470 degree days on the trunks and leaves of the host plant or nearby surfaces, including brick walls, decks, and outdoor furniture. Adults are present from late October to early December, are diurnal, have a weak fluttering flight pattern, and are most commonly seen flying at midday. After mating, egg clusters of 100 to 200 eggs are laid on the tips of twigs and undersides of leaves on the host plants. Each egg cluster has a fine covering of setae from the female abdomen. The insect overwinters in the egg stage. 


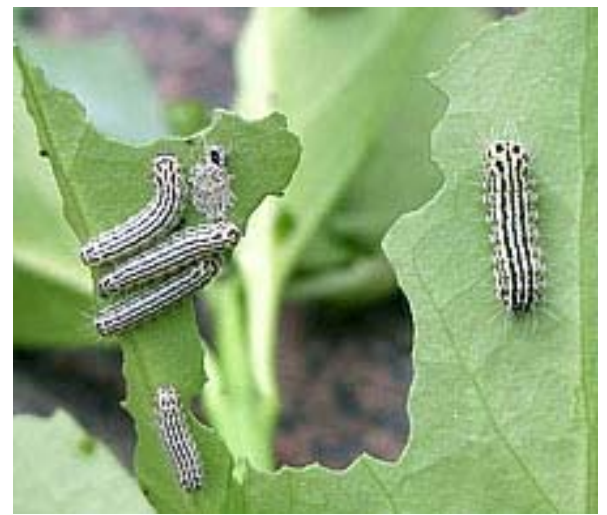

Fig. 1. Pryeria sinica larvae feeding on euonymus foliage.

\section{Literature Cited}

1. Brown, J. W. 2003. Biology statement: Pryeria sinica Moore (Lepidoptera Zygaenidae) newly recorded for the United States. Online. Dept. of Entomol., Virginia Tech, Blacksburg.

2. Yen, S.-H., and Horie, K. 1997. Pryeria sinica Moore (Lepidoptera, Zygaenidae), a new newly discovered relic in Taiwan. Trans. Lepid. Soc. J apan 48:39-48. 